\title{
Correction to: Musculoskeletal pain and its correlates among secondary school female teachers in Aljouf region, Saudi Arabia
}

\author{
Doaa M. Abdel-Salam ${ }^{1,2} \cdot$ Alanoud S. Almuhaisen ${ }^{3} \cdot$ Rahaf A. Alsubiti $^{3} \cdot$ Nouf F. Aldhuwayhi $^{3} \cdot$ Faridah S. Almotairi $^{3}$. \\ Shikhah M. Alzayed ${ }^{3}$. Farah F. Bakri ${ }^{3}$
}

Published online: 24 August 2019

(C) Springer-Verlag GmbH Germany, part of Springer Nature 2019

\section{Correction to: J Public Health (Berl.): From Theory to Practice https://doi.org/10.1007/s10389-019-01127-8}

The article Musculoskeletal pain and its correlates among secondary school female teachers in Aljouf region, Saudi Arabia, written by Doaa M. Abdel-Salam, Alanoud S. Almuhaisen, Rahaf A. Alsubiti, Nouf F. Aldhuwayhi, Faridah S. Almotairi, Shikhah M. Alzayed, Farah F. Bakri, was originally published electronically on the publisher's internet portal (currently SpringerLink) on 29 July 2019 with open access. With the author(s)' decision to step back from Open Choice, the copyright of the article changed on 13 August 2019 to () SpringerVerlag GmbH Germany, part of Springer Nature 2019 and the article is forthwith distributed under the terms of copyright.

Publisher's note Springer Nature remains neutral with regard to jurisdictional claims in published maps and institutional affiliations.

The online version of the original article can be found at https://doi.org/ 10.1007/s10389-019-01127-8

Doaa M. Abdel-Salam

dabdelsalam@ju.edu.sa; doodyas2004@yahoo.com

1 Family and Community Medicine Department, College of Medicine, Jouf University, Aljouf 42421, Saudi Arabia

2 Public Health and Community Medicine Department, Faculty of Medicine, Assiut University, Assiut 71526, Egypt

3 Medical student, College of Medicine, Jouf University, Aljouf 42421, Saudi Arabia 